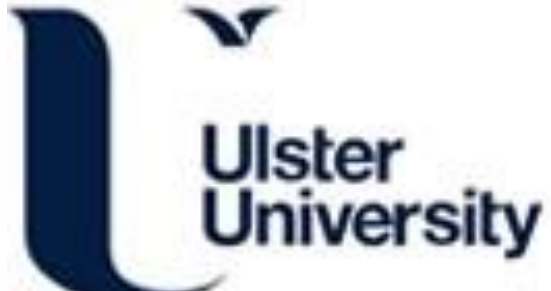

\section{Crows on the Wire: intermediality in applied drama and conflict transformation - 'humanising'the police in Northern Ireland}

Jennings, M. (2016). Crows on the Wire: intermediality in applied drama and conflict transformation -

'humanising'the police in Northern Ireland. Research in Drama Education: the Journal of Applied Theatre and Performance, 21(3), 418-430. https://doi.org/10.1080/13569783.2016.1194194

Link to publication record in Ulster University Research Portal

\section{Published in:}

Research in Drama Education: the Journal of Applied Theatre and Performance

Publication Status:

Published online: 30/06/2016

DOI:

10.1080/13569783.2016.1194194

\section{Document Version}

Author Accepted version

\section{General rights}

Copyright for the publications made accessible via Ulster University's Research Portal is retained by the author(s) and / or other copyright owners and it is a condition of accessing these publications that users recognise and abide by the legal requirements associated with these rights.

\section{Take down policy}

The Research Portal is Ulster University's institutional repository that provides access to Ulster's research outputs. Every effort has been made to ensure that content in the Research Portal does not infringe any person's rights, or applicable UK laws. If you discover content in the Research Portal that you believe breaches copyright or violates any law, please contact pure-support@ulster.ac.uk. 


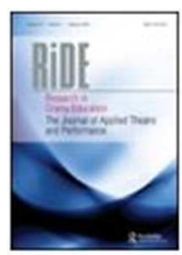

Crows on the Wire: Intermediality in applied drama and conflict transformation -'humanising' the police in Northern Ireland

\begin{tabular}{|r|l|}
\hline Journal: & $\begin{array}{l}\text { Research in Drama Education: The Journal of Applied Theatre and } \\
\text { Performance }\end{array}$ \\
\hline Manuscript ID & CRDE-2015-0101.R3 \\
\hline Manuscript Type: & Themed Issue Paper \\
\hline Keywords: & $\begin{array}{l}\text { Applied Drama, Conflict Transformation, Northern Ireland, Intermediality, } \\
\text { Digital Performance }\end{array}$ \\
\hline \multicolumn{2}{|l}{} \\
\hline
\end{tabular}

SCHOLARONE ${ }^{m}$

Manuscripts 
Crows on the Wire: Intermediality in applied drama and conflict transformation -'humanising' the police in Northern Ireland

Key words: Applied Drama; Conflict Transformation; Northern Ireland; Intermediality; Digital Performance

Word Count: 5,030 
Abstract: Crows on the Wire is an intermedial project deploying applied theatre, educational drama and digital performance (Dixon 2007) to explore the recent history of the peace process in Northern Ireland - specifically the 'transition' of the police force from the Royal Ulster Constabulary (RUC) to the Police Services Northern Ireland (PSNI) in November 2001. This 'rebranding' was a key element of the Good Friday Agreement (1998) that nominally ended the civil conflict known as 'The Troubles'. The Crows on the Wire project (COTW), delivered by the Verbal Arts Centre (VAC) based in Derry/Londonderry, expresses the anger and disaffection felt by some members of the RUC and the impact that this had on their sense of identity. It also addresses the perception that the RUC was sectarian and corrupt.

The project presented three distinct modes of applied performance, linked by an ethos and aesthetic of 'purposeful storytelling' (Verbal Arts Centre 2013b). The first element was a play, Crows on the Wire (Burgess 2013) which was widely performed across Northern Ireland. 71\% of Catholic audience members reported a 'change in perception regarding the RUC', while $97 \%$ of audiences agreed that 'theatre was an effective way to explore sensitive issues’ (Fearon Consulting, COTW Evaluation report, 2014)

The second element was an educational programme of drama workshops for schools and community groups, providing experiential and interpersonal exploration of conflict and identity. Many young people had little knowledge of the history of policing in Northern Ireland, beyond inherited attitudes towards the state.

The third element is a digital media project, generating 'mutual affect' (Kattenbelt 2008) through the intermediality of the theatrical production, drama workshops, online video documentation and an 'App' for tablet computers. This 'intermediality' provides a virtual space for 'rhizomatic deterritorialisation' (Deleuze and Guattari 1987), disrupting conventional paradigms of knowledge, ethics and aesthetics.

\section{Crows on the Wire - Context: historical and political issues}

The 'Belfast Agreement' of 10 April 1998 (commonly known as the Good Friday Agreement) established the Independent Commission on Policing in Northern Ireland to investigate ways to improve the 'efficiency, accountability and acceptability' of the police service (Patten 1999, 2). The 'Patten Commission' recommended to disband the 'contentious' Royal Ulster Constabulary (RUC) and replace it with a new Police Service of Northern Ireland (PSNI) 'capable of attracting and sustaining support from the community as a whole' (Patten 1999, 1). This ‘transition' took place on 4 November 2001.

Little thought was given as to how individual RUC officers felt about this judgement of their 'efficiency, accountability and acceptability'. While Patten described police as both 'victim and participant in past tragedies' $(1999,2)$, in stating that Northern Ireland required a new service 'accountable, both under the law for its actions and to the community it serves' (Patten 1999, 5), the implication was that the RUC had not been such a service.

While existing officers could go straight into the ranks of the PSNI, the Commission also recommended a policy of 'positive discrimination' in the recruitment of Catholics to the new service, intended to reduce the substantial Protestant majority in the RUC and its perceived bias against Irish Nationalists and Republicans. In 1998, only 7.5\% of RUC officers were Catholic and $0 \%$ identified as Nationalist (Mulholland 2003, 146). The policy of 'affirmative action' was discontinued in March 2011. Today, 30\% of PSNI officers come from Catholic backgrounds (PSNI Workforce Composition Figures 2015). 
Throughout the 'Troubles' (the period of civil conflict in Northern Ireland usually dated from 1968 to 1998), the RUC was accused of criminal collusion, as well as bias (Melaugh/CAIN 2013). There is 'indisputable evidence' (Cadwallader 2012) that British military and police officers colluded in the murder of Protestant and Catholic civilians in Northern Ireland. The third report of the Lord Stevens enquiries found that RUC officers, MI5, MI6 and the Forces Research Unit (FRU) of the British Army had engaged in 'disastrous collusion' with members of the PIRA, the UDA and the UVF in the murders of dozens, if not hundreds, of civilians. In a press conference, Stevens said 'a lot of innocent people were killed' and 'there has to be regard for the rule of law, otherwise we will descend into chaos' (Hopkins and Cowan 2003).

According to former police officers involved in this project, many felt that they had actually been defending 'the rule of law' and protecting 'innocent people' throughout their careers, at great personal risk. In 1999, the RUC had received the George Cross for 'collective courage and dedication to duty' in facing the 'danger and stress this has brought to them and their families' (Buckingham Palace George Cross citation 1999), only the second collective award after that given to the population of Malta in 1942. Yet Patten condemned the whole force for the crimes of a few. According to former Superintendent Roger McCallum (trustee for RUC George Cross Foundation ), officers in 'the police family' saw themselves as a 'third community', beyond and between the conflicting groups in Northern Ireland, unfairly portrayed as a corrupt force representing an oppressive state: 'Collusion and corruption were only perpetrated by a small number of police officers. But the reputation of the whole force was tarnished by their actions. A lot of us felt betrayed by the government in 2001' (interview with the author, 15 March 2013).

The categories of 'innocence' and 'victimhood' are disputed territory in Northern Ireland, relating to contested histories of the conflict; the financial implications of compensation; the legitimacy of the governing institutions; and the moral framework of the peace process as a whole (Graham 2014). A systematic 'truth recovery' process might enable disclosure of past crimes and state involvement, in the manner of the South African Truth and Reconciliation Commission; a 'Legacy Commission' was recommended by the 'Eames/Bradley' report (Northern Ireland Affairs Committee 2009), but it was rejected amid controversy over the payment of compensation to victims' families and the inclusion of former paramilitaries (Rowan 2010). In its absence, sporadic apology and limited investigation of individual murders contribute to an atmosphere of antagonism and mistrust.

Recent enquiries into historical killings have heightened political tensions, such as when the PSNI questioned and detained Gerry Adams in May 2014 in relation to the 1972 murder of Jean McConville (McDonald 2014). Conversely, the British government ruled out an independent enquiry into the murder of lawyer Pat Finucane, despite David Cameron's 'apology' after the de Silva report found evidence of collusion by MI5, MI6, FRU and RUC officers (McDonald and Bowcott 2012). These tensions endanger the fragile political process in Northern Ireland. Unionist parties rejected Richard Haass' proposed mediation on 'legacy' issues in December 2013 (McDonald 2013). Sinn Fein threatened to withdraw support for 
policing at the time of Adams' detention (McDonald 2014). The position of policing in Northern Ireland continues to be contentious.

One response to this situation has been Crows on the Wire (2013-2015), an intermedial project that deploys applied theatre and 'digital performance' (Dixon 2007) to explore the recent history of Northern Ireland; specifically, the 'transition' of the police force from the RUC to the PSNI. The Crows on the Wire (COTW) project, delivered by the Verbal Arts Centre (VAC) based in Derry/Londonderry, addresses the anger and disaffection felt by some members of the RUC and the impact that this had on their sense of identity. The primary funding for the COTW project initially came from the Special European Union Programmes Board (SEUPB) Peace 3 programme, under the strand called 'Acknowledging and Dealing with the Past'.

The VAC identified the project as an example of its ethos of 'purposeful storytelling' (Verbal Arts Centre 2013b), defined as 'a transformational, leadership art, open to all, through which we translate values into action' (Verbal Arts Centre 2015). This concept draws on Marshall Ganz' principle of 'public narrative' as an instrument of social change (2008). The project developed through three distinct modes of applied performance:

1. A professionally produced touring play

2. A series of educational and community workshops and seminars

3. An online presence, including the project website, a series of Youtube videos, and an interactive 'App' for Android and iPad tablets.

The first two stages were conceived at the outset of the project; the third emerged from discussions with participants and audiences. As shall be discussed further, in the terminology of Deleuze and Guattari (1987), this development represents an evolution from an 'arboreal' model of cultural production (with the text as the 'stem' of all social, aesthetic and educational offshoots) into an increasingly 'rhizomatic' network of 'intermedial' live and digital events.

\section{Crows on the Wire 1.0 - Text: Dramaturgy and live performance}

The original play, Crows on the Wire (2013), was conceived by writer Jonathan Burgess, following conversations with former RUC officers in 2003 (interview with author, 29 March 2014). In 2012, the VAC agreed to produce the play as part of a community and educational programme, employing me to provide dramaturgical input as a 'Peer Support Writer'.

The play initially presented an Aristotelian 'tragic hero' in the character of long-term RUC officer, 'Jack', an overweight recovering alcoholic and divorcee estranged from his family, suffering from trauma and possibly depression. He describes himself, and the RUC as a whole, as 'scapegoats' to political expediency. The title of the play refers to a local farming tradition, whereby dead crows are hung from wires to scare living crows away from the crops. It signifies punishment and warning - 'scarecrows' as well as 'scapegoats' - grisly sacrifice to prevent further transgression. 
The scapegoat, ('pharmakos' in Greek), is sacred and profane, a carrier of communal sins whose expulsion heals the social order. One prime example of the pharmakos is Oedipus, an abject figure banished from the city of Thebes in order to save it from plague. In Sophocles' plays, Oedipus takes asylum in the sacred grove of Colonus, where his refugee status makes him a 'divine outsider' and saviour of Athens (Eagleton 2003; 2009). In classical morality and dramaturgy, the 'tragic hero' carries society's sins outside of the polis ('city' in Ancient Greek; Scots for 'police') redeeming both self and other. The 'victim and participant' is sacrificed to cleanse the curse of history.

We hoped that Jack's narrative would provoke passionate and informed post-show discussion, without alienating potential audiences. Before script development began, performances had already been booked in both Loyalist and Republican cultural centres - it would be presented to people who had been attacked by security forces, as well as people who had served in those forces. Some had lost loved ones, from both sides of the conflict. Also, as the VAC was delivering a programme of workshops and performances for secondary schools, the play had to be accessible to young people with little or no personal experience of the RUC. Yet we did not want to replicate the wilful amnesia and hegemonic optimism of the 'peace industry' (Grant and Jennings 2013; Jennings and Grant 2013; Baker and McLaughlin 2010). Burgess was keen to challenge the 'beige loveliness' (interview with author, 29 March 2014) of much post-conflict theatre in Northern Ireland.

In my view, the dramaturgical task included two key elements: firstly, the narrative should develop the dramatic action and conflict between characters, rather than framing a series of monologues; and secondly, the play should represent multiple perspectives, in counterpoint to Jack's bitter cynicism. Our aim was to engage audiences with a compelling story that raised difficult questions and stimulated discussion, not just vent the outrage of one damaged man; to highlight the bravery of rank and file officers, but also acknowledge the 'contentious' history of policing.

The first draft hinged on a set of speeches describing Jack's sense of betrayal and the horrors that he had experienced in service. The most 'verbatim' element of the play (drawn from a conversation Burgess had with a former RUC officer in 2003) was a monologue about an IRA car bomb that had left Jack's best friend and fellow officer, 'Tom', dying in Jack's arms. Tom's legs were shredded - 'straggling wee wisps of flesh, like red elastic bits of things trailing off'. Jack is traumatised by this memory and this feeds his resentment of the political process:

There was this prick on [television] one night after all this peace and loveliness broke out, talking about the need for us all to forgive each other and the need for community regeneration through healing and dealing with the past...But do you know where his theory falls down? The bastard's never woke up crying like a wean [child] in the middle of the night with the smell of burning flesh in his nostrils. 
In order to balance Jack's perspective, we began by enhancing the actions, objectives and backgrounds of the other characters: 'David', a recent graduate and new recruit to the RUC, who embraces the transition to the PSNI as an opportunity for a fresh start and is initially dismissed by Jack as an ignorant and selfish careerist; and 'Ruth', a female officer who resigned from the RUC years ago, partly due to sexual harassment she had encountered during her service.

Within the play, Jack claims to have spent his life maintaining order in the face of the 'terrorism' that has threatened his family and community. He sees that battle as being lost in the 'betrayal' of the RUC by the government. In response, David, condemns the criminal collusion of some RUC officers and fears that this could continue if 'dinosaurs' like Jack do not change. Ruth expresses sympathy for Jack, but suggests that many of his problems are of his own making, such as his destructive relationship with his family. Jack's violence and drinking have alienated his son, who has become involved in petty crime and drug abuse. Ruth tries to persuade Jack to save his son from a paramilitary punishment beating. In order to be a better police officer, she says, he also needs to be a better father.

The play included certain Brechtian elements: an episodic, non-linear structure; direct-toaudience monologues; and recordings of poems and messages posted by police officers on 4 November 2001, 'the night in question'. Significant dramaturgical input was contributed by the director, Caitriona McLaughlin, who has worked in London, New York and Dublin, but is originally from Donegal and started out in youth theatre in Derry/Londonderry in the 1990s. As a Catholic Nationalist woman, McLaughlin offered an important counterpoint to Burgess' male, Presbyterian, Unionist perspective.

The touring production played to capacity houses in theatre and community venues across Northern Ireland in November 2013, provoking heartfelt and thoughtful exchanges in the post-show discussions, as can be seen online (Verbal Arts Centre 2014a). Audiences empathised with what the officers had experienced, including people who describe themselves as Nationalist or Republican:

"I thoroughly enjoyed the exploration of the perspective of that group of people; the former RUC. I would never have had the opportunity otherwise to share that perspective, to walk in the other guy's shoes."

Irish Republican, Stranmills

"The show made me rethink about my views and realise that it was people that wore the uniform."

Irish Catholic, An Grianan

"They're human and have suffered. It was a brilliant performance."

Irish Nationalist - Coalisland

(Italics in original) Fearon Consulting 2014, 10 
$60 \%$ of audience members reported a 'change in perception regarding the RUC' after seeing the performance. Significantly, $71 \%$ of audiences from a 'Catholic, Nationalist, Republican community' indicated such a change of perception. While $43 \%$ identified as Catholic and $16 \%$ as other, $41 \%$ of audiences described themselves as 'Protestant/Unionist/Loyalist', a 'much higher than average level of engagement by the PUL community with the project' (Fearon Consulting 2014, 7). Many former RUC officers and their family members felt validated, able to express perspectives that had not been presented publicly before (Fearon Consulting 2014). Regarding the efficacy of applied theatre, $97 \%$ of audiences agreed that 'theatre was an effective way to explore sensitive issues' (Fearon Consulting 2014, 8).

The online video evaluation includes interviews with current and former police officers, as well as a former IRA prisoner, expressing reflective but unrepentant views of their actions during the 'Troubles' (Verbal Arts Centre 2013a). The intention was to provoke discussion of the personal and political impact of the conflict, raising difficult issues, so that communities might examine their assumptions and survivors might address its legacy.

The aim was to 'humanise the police officer, rather than the police force as a whole'. This statement resonated with delegates at the International Community Arts Festival (ICAF) 2014 in Rotterdam, during a seminar on community arts and policing (Jennings and Sutherland, 28 March 2014). Practitioners from the Philippines Education Theatre Association (PETA), Grupo Cultural Yuyachkani, and Imaginaction particularly responded to this concept, despite personal experienced of state-sponsored violence in the Philippines, Peru, Colombia and the US. After decades of oppression and resistance, these companies have recently begun working with police officers internationally. Several other artists at ICAF 2014 shared anecdotes of productive exchanges with police officers on cultural projects in Europe, South America, North America and Asia. Maguire has pointed out that peace initiatives in Northern Ireland often emphasise the 'shared humanity' of combatants, a cultural strategy that can deflect attention from structural and political causes of conflict and reinforce state control (2006). Yet these practitioners asserted that, in many cases, creative participation had supported constructive dialogue and relationship-building between police and communities, decreasing antagonism and state intervention.

\section{Crows on the Wire 2.0 - Intertext: community engagement and AV material}

The project also involved a series of 'outreach' educational drama workshops, delivered to 17 secondary schools and eight community relations groups by freelance drama facilitator, Sorcha Shanahan, and Mhairi Sutherland (COTW Community Engagement Facilitator). The first series of workshops began in September 2013, before the November production of the play, planned as part of a process of community consultation, script development and educational outreach. The workshops could 'act as a stand-alone piece of work, but could best complement further attendance at a performance of COTW' (Fearon Consulting 2014, 12). Rehearsed readings of selected scenes were filmed, using locally based actors, and distributed through discreet online sources. These filmed extracts were used as stimuli for a 
series of participatory activities, such as Image Theatre (Boal 2000) and process drama (O’Neill 1995), generating discussion of participant responses to the scenes and their perspectives on the historical context. This represented a process of 'dialogical pedagogy' (Freire 1970), a mutual exchange of teaching and learning between facilitators, participants and the production team. Interactive drama activities also enhanced opportunities for affective understanding through 'kinesthetic empathy', provoking sensory responses to the experiences and actions of others (Jennings and Grant 2013; Reason and Reynolds 2012).

The workshop format was piloted at a weekend retreat in June 2012 organised by the Northern Ireland Phoenix Project, a support group for military and police service personnel and their families. The workshop was tested with three different groups of former RUC officers and their family members:

People were saying that their biggest problem was that the stories shouldn't be told at all - that they were too personal and that what happened behind the uniform should never be revealed to anyone who had never experienced that themselves. There were issues with language - the language in some of the scenes is quite strong.

Shanahan, EAF seminar 18 July 2015

In relation to the issue of strong language, this concern raised the most controversy and was extensively discussed during the script development process. There were queries from higherranking officers about the inclusion of swearing in a performance attended by schoolchildren:

They were uncomfortable with the idea of police officers speaking like that - or people hearing police officers speaking like that...We were asking: "Is there something wrong with the authenticity of it?" And they were saying: "No, no. People would have spoken like that. But we're uncomfortable with other people knowing that."

Sutherland, EAF seminar 18 July 2015

Finally, the VAC defended the use of strong language on the basis of the 'authentic' and personal nature of the narrative. It enhanced the potential for empathy, showing the 'human face' behind the official persona:

It's a very human play. It's told from the perspective of the individual and shows the impact of change on the individual, rather than presenting the story of an institution.

Sutherland, EAF seminar 18 July 2015

The pilot workshops were deemed a success and a similar format was used for a programme of school and community group workshops running from September and October 2013, before the tour of the play. Each session included ice-breakers and introductory drama activities, before filmed scenes were used as stimuli for group discussion and further interactive drama activities. When participants from these preliminary workshops attended 
the play, their familiarity with the material helped them to engage confidently in the postperformance 'Question \& Answer' sessions:

The workshops introduced drama as a way to explore difficult issues, personalise the topic - which was one of the main aims of the project - and encourage audience participation and discussion. It was really clear whenever the people that had taken part in the workshops then went and saw the play. They were much more comfortable speaking out and getting involved in the discussions.

Shanahan, EAF seminar 18 July 2015

For schoolchildren, the drama workshops provided an opportunity for experiential learning that challenged fixed perceptions of conflict and identity and explored the historical context of these perceptions. Many had little knowledge of the history of policing in Northern Ireland, beyond inherited attitudes towards the state. According to the COTW project evaluation, $25 \%$ of 125 students participating in COTW workshops indicated before the workshops that they 'did not know' who or what the RUC had been. On the other hand, 43\% of respondents indicated that they felt that the role of the RUC was 'to protect Protestant communities only'. Many ticked multiple answers to the same question, indicating a general lack of a 'clear understanding or knowledge of the RUC' (Fearon Consulting 2014, 14).

Conversely, after the workshops and performance, students expressed a greater understanding of the current and historical personal situation of police officers in Northern Ireland:

The kids said things like "oh, I've never seen it from that perspective" or "whenever she said that, I got that" or "his reaction, that's how I would feel ". So, it really personalised it and made the themes and issues much more real to the workshop participants, which was the point.

Shanahan, EAF seminar 18 July 2015

\section{Crows on the Wire 3.0 - Hypertext: 'App' drama}

The COTW interactive 'App' is available for download anywhere, although it only operates on Android and iPad tablets (Verbal Arts Centre 2014b). It was developed with Belfast-based digital media production company, Blacknorth. The VAC had originally hired Blacknorth to develop a graphic novel based on the play and the idea of the App emerged from that collaboration, partly in response to participant enthusiasm for the online filmed extracts used in the drama workshops (Sutherland, EAF seminar 18 July 2015). The App was intended for secondary schools, to support the Key Stage 3 Local and Global Citizenship curriculum, as developed by the Council for the Curriculum, Examinations and Assessment (CCEA 2015). The COTW resources were created with a CCEA advisor and were 'designed to stimulate young people to consider how the past influences the present, and to explore themes such as cultural identity, sectarianism, conflict, change, commemoration, equality and the role of the younger generation' (Verbal Arts Centre 2014b). 
It was really important that the form of the App would appeal to young people, that it was something that was really 'funky', that it was accessible...As well as telling the specific story of these individual characters, it is also intended to aid the teaching of controversial issues in schools in Northern Ireland.

Sutherland, EAF seminar 18 July 2015

The COTW App contains six 'chapters', each corresponding to a chapter of the graphic novel. Each chapter contains a series of 'comic book' panels, some of which include animation and audio-visual effects. For instance, after one character says that the phrase 'natural justice' reminds him of 'crocodiles eating zebras', there is an animated image of a crocodile eating a zebra, accompanied by munching sounds of crunching. Each section includes links to filmed extracts of the play (re-shot in actual working police stations), as well as teaching and learning resources from other websites (such as the BBC Northern Ireland archives) for further investigation of related issues.

The App contains 'layers' of narrative, discourse, imagery, sound and educational information - 'a big fat onion', as Sutherland says:

It's a graphic novel, it's a series of films, it's a series of teachers' resources and it's a series of pupils' resources. It can also connect to Facebook so, as people are working their way through it, they can give an instant comment.

EAF seminar, 18 July 2015

In this sense, the App represents the 'rhizomatic' and 'intermedial' development of the project (see below). Workshops, performances, community dialogue, filmed extracts and online responses created an impetus that led to new and proliferating platforms for live and digital interaction, each element of the project transforming the others.

From 2014 to 2015, workshops demonstrating the App were held in 'Integrated Schools', as well as 'Controlled Schools' and 'Maintained Schools'. Most students in Northern Ireland attend either predominantly Protestant 'Controlled Schools' or 'Catholic Maintained Schools' (DENI 2015b). Only 7\% of all pupils in Northern Ireland were enrolled in 'Integrated Schools' in 2014/15 (DENI 2015a). Tablets were used to record student responses to the App demonstration workshop, with students from each type of secondary school expressing high levels of interest and enthusiasm, as can be seen from the online 'Vox Pop' video (Verbal Arts Centre 2014c). It is important to note that students still valued live interaction. As one student said, the filmed scenes on the App present 'probably the most effective way to understand what the characters were going through at the time', yet 'doing all the drama activities really helped to understand the characters and work all the stuff out' (Verbal Arts Centre 2014c).

In November and December 2014, a UK-based educational technology company, iTeach, integrated demonstrations of the COTW App into its teacher training sessions in 84 schools, across the 6 counties of Northern Ireland and three border counties in the Republic of Ireland. The response from schools, on both sides of the border, was 'overwhelmingly positive with a 
particular emphasis on ease of use', although strong language again caused some concern: 'The single request for change surrounded the use of expletives in some of the content, with staff simply requesting a warning on the app overview' (iTeach Crows on the Wire report 2015).

\section{Multimediality, Transmediality and Intermediality}

Kattenbelt provides a useful set of definitions to distinguish between the terms 'multimediality', 'transmediality' and 'intermediality':

To phrase it very briefly, "multimediality" refers to the occurrence where there are many media in one and the same object; "transmediality" refers to the transfer from one medium to another medium (media change); and "intermediality" refers to the corelation of media in the sense of mutual influences between media.

$(2008,21)$

In these terms, 'multimedia' refers to the fact that a performance (or performative space, such as a website) may include audio-visual, textual, sonic and other forms of representation (Kattenbelt 2008). In this regard, the Crows on the Wire live performances, website, online videos and App all included multimedia elements within each 'object'. In terms of the 'transmedial' transfer from one medium to another, the content of the Crows on the Wire play was 'translated' into numerous forms: the graphic novel; the filmed scenes; the video clips; a hard copy publication of the script; and the App itself, which linked all of these in a multimodal format.

For the purposes of this article, the most significant of these terms is 'intermediality'. Kattenbelt defines intermediality as 'those co-relations between different media that result in a redefinition of the media that are influencing each other, which in turn leads to a refreshed perception. Intermediality assumes a co-relation in the actual sense of the word, that is to say a mutual affect' $(2008,25)$. The interweaving of the 'multimedia' and 'transmedia' elements of the COTW project, within and around the programme of educational drama and community dialogue, generated a dynamic phenomenon of 'intermediality', transforming the overall project and 'refreshing' the perception of its individual elements. 'Intermediality assumes an in-between space - "an inter" - from which or within which the mutual affects take place' (Kattenbelt 2008, 26). The COTW App is such 'an inter' - a space where contradictory histories, challenging perspectives and diverse media transform each other in a 'mutual affect'.

The App links the COTW project to wider networks of information and provides suggestions for further investigation and input. As new elements are added - links, blogs and social media 'shares' - new users challenge and change the significance of the other elements. The App is not simply a tool for broader dissemination of the stories told in the play, a means of reaching more students with the message that 'police are people too'. It creates a space within which real and virtual communities can grapple with issues, play with forms, and explore the 
convergence between art and politics. 'Intermediality refers particularly to the correlation between art, science and ethics (politics) as a conscious striving for a breaking open of the cultural value spheres or action domains' (Kattenbelt 2008, 27). This App uses 'art, science and ethics' in an attempt to 'break open' the 'cultural value spheres' of conflict, community and identity, evoking the 'rhizomatic deterritorialization' of Deleuze and Guattari (1987).

\section{Rhizome and Hypertext}

A 'rhizome' is a metaphor drawn from nature, a centreless network of interwoven roots and fibres, like vines, hedges and grass. The 'rhizome' invokes the principles of connection, heterogeneity and multiplicity - 'any point of a rhizome can be connected to anything other, and must be' (Deleuze and Guattari 1987, 7). As Hamman (1996) and Wray (1998) have pointed out, the rhizome prefigures the structure of the internet itself.

The rhizome is opposed to the 'arboreal' model, the normative 'tree of knowledge', whereby languages and identities are presented as branches growing from a central stem of sanctioned textual 'truth'. 'There are no points or positions in a rhizome, such as those found in a structure, tree, or root. There are only lines' (Deleuze and Guattari 1987, 8). Fixed histories and monolithic conceptions of identity reinforce the rigid arboreal paradigm, imposing a centralising unity on the diversity of experience. Alternatively, 'rhizomatic deterritorialization' can take the form of a 'hypertext':

Like the rhizome, hypertext, which has 'multiple entryways and exits,' embodies something closer to anarchy than to hierarchy, and it 'connects any point to any other point,' often joining fundamentally different kinds of information and often violating what we understand to be both discrete print texts and discrete genres and modes.

Landow 1997, 41

The COTW App represents a 'hypertext' whose 'multiple entryways' enable anarchic disruption of texts, genres and modes. This 'violation' in turn disrupts other textual and generic hierarchies, such as the validation of 'official history' over personal experience, or homogenous narratives of identity and nationality over fluidity and diversity.

\section{Post-text}

Intermediality results in 'new forms of representation; new dramaturgical strategies...generating new cultural, social and psychological meanings' (Kattenbelt 2008, 21 ). Initially, the play set out to challenge the official version of the peace process as an unmitigated success, presenting a dissenting voice of personal grief. Then, script development disrupted its polemical monologues with an Aristotelian dramaturgy of action and conflict. The final production incorporated intertextual elements, Brechtian aesthetics and 
dialectical discourses in order to reflect contested narratives and a broader historical context. Online video material, educational drama workshops and community discussion informed the production. This process of dialogical pedagogy and participatory drama evolved into an interactive network of live and virtual events, objects and spaces, as epitomised by the COTW App. Each of these 'new forms of representation' generates 'new cultural, social and psychological meanings'. The App is a 'map' with blank spaces for new explorers - no matter where they live or who they might be; expanding opportunities for communication, education and interaction, beyond the territoriality of time, place or identity.

\section{REFERENCES}

Baker, S., and G. McLaughlin. 2010. The propaganda of peace: The role of media and culture in the Northern Ireland peace process. Bristol: Intellect Books.

Boal, A. 2000. Theatre of the Oppressed. Trans. C.A. McBride, M. Leal McBride and E. Fryer. London: Pluto Press (Orig. pub. 1974)

Burgess, J. 2013. Crows on the Wire. Derry/Londonderry: Lagan Press

Cadwallader, A. 2012. Lethal Allies: British Collusion in Northern Ireland. Cork: Murcier Press

Council for the Curriculum, Examinations and Assessment (CCEA). 2015. Northern Ireland Local and Global Citizenship Curriculum.

http://www.nicurriculum.org.uk/key_stage_3/areas_of_learning/learning_for_life_and_work/ local and global_citizenship.asp (accessed 15 August 2015)

Deleuze, G., and F. Guattari. 1987. A thousand plateaus: Capitalism and schizophrenia. Trans. B. Massumi. Minneapolis: University of Minnesota Press

Department of Education Northern Ireland (DENI). 2015a. Integrated schools. https://www.deni.gov.uk/articles/integrated-schools (accessed 15 August 2015)

Department of Education Northern Ireland (DENI). 2015b. Information on school types in Northern Ireland. https://www.deni.gov.uk/articles/information-school-types-northernireland (accessed 10 January 2016)

Dixon, S. 2007. Digital performance: A history of new media in theatre, dance, performance art and installation. Cambridge, MA and London: MIT Press

Eagleton, T. 2003. Sweet violence: The idea of the tragic. Oxford: Wiley-Blackwell Publishing

Eagleton, T. 2009. Trouble with strangers: A study of ethics. Oxford: Wiley-Blackwell 
Fearon Consulting. 2014. 'Crows on the Wire' Evaluation Report. Derry/Londonderry: Verbal Arts Centre

Freire, P. 1970. Pedagogy of the Oppressed. Trans. M.B. Ramos. New York: Continuum.

Ganz, M. 2008. What is public narrative? http://chutzpahportfolio.yolasite.com/favresources.php (accessed 5 January 2016)

Graham, L. 2014. The "innocent" victims of the Troubles and the enduring impediment to peace in Northern Ireland. Shared Space: A research journal for Northern Ireland 17: 37-53

Grant, D., and M. Jennings. 2013. Processing the Peace: An Interview with Teya Sepinuck. Contemporary Theatre Review 23, no. 3: 314-322.

Hamman, R. B.1996. Rhizome@Internet. Using the Internet as an example of Deleuze and Guattari's 'Rhizome'. http://www.socio.demon.co.uk/rhizome.html. No longer available

Hopkins, N., and R. Cowan. 2003. Scandal of Ulster's secret war. The Guardian 17 April 2003. http://www.theguardian.com/uk/2003/apr/17/northernireland.northernireland2 (accessed 27 August, 2014)

iTeach. 2015. iTeach Crows on the Wire report. Derry/Londonderry: Verbal Arts Centre. Jennings, M., and D. Grant. 2013. 'Peace Industry Propaganda or 'Troubles Porn'?: Ethics, Aesthetics and Kinaesthetics in Northern-Ireland's Theatre of Witness', in E. van Erven (ed.) Community/Art/Power: Essays from ICAF 2011. Utrecht: University of Utrecht, 70-84

Jennings, M., and M. Sutherland. 2014. 'Crows on the Wire: Community Arts and Policing' seminar (with Dr Kerrie Schaefer). International Community Arts Festival (ICAF), 28 March 2014

Kattenbelt, C. 2008. Intermediality in theatre and performance: Definitions, perceptions and medial relationships. Cultura, lenguaje y representacion/Culture, language and representation 6: 19-29.

Landow, G. 1997. Hypertext 2.0. Baltimore: John Hopkins University Press

McDonald, H., and O. Bowcott. 2012. Pat Finucane report: David Cameron apologises over killing. The Guardian 12 December 2012. http://www.theguardian.com/uk/2012/dec/12/patfinucane-report-david-cameron-apologises (accessed 2 September 2014)

McDonald, H. 2013. Northern Ireland talks collapse as main unionist parties reject Haass proposals. The Guardian 31 Dec 2013, http://www.theguardian.com/uk-

news/2013/dec/31/northern-ireland-talks-collapse-as-main-unionist-parties-reject-haassproposals (accessed 2 May 2014)

McDonald, H. 2014. Gerry Adams arrest defended by Northern Ireland police chief. The Guardian 6 May 2014, http://www.theguardian.com/politics/2014/may/06/gerry-adamsarrest-defended-northern-ireland-police-chief (accessed 27 August 2014) 
Maguire, T. 2006. Making Theatre in Northern Ireland: Through and Beyond the Troubles. Exeter: University of Exeter Press.

Melaugh, M. 2013. Frequently Asked Questions. CAIN (Conflict Archive on the Internet) http://www.cain.ulst.ac.uk/faq/index.html (accessed 15 August 2014)

Mulholland, M. 2003. Northern Ireland: a very short introduction. Oxford: OUP

Northern Ireland Affairs Committee. 2009. The Report of the Consultative Group on the Past in Northern Ireland.

http://cain.ulst.ac.uk/victims/docs/consultative_group/cgp_230109_report.pdf (accessed 10 January 2016

O'Neill, C. 1995. Drama Worlds: A Framework for Process Drama (The Dimensions of Drama). Oxford: Heinemann.

Patten Report. 1999. A new beginning: Policing in Northern Ireland (Independent Commission on Policing for Northern Ireland).

http://cain.ulst.ac.uk/issues/police/patten/patten99.pdf (accessed 22 August 2014)

Police Service of Northern Ireland (PSNI). 2015. Workforce Composition Figures 1.08.2015. http://www.psni.police.uk/updates_workforce_composition_figures (accessed 15 August 2015)

Reynolds, D., and Reason, M., eds. 2012. Kinesthetic empathy in creative and cultural practices. Bristol: Intellect

Rowan, B. 2010. Eames-Bradley: Saville Report 'has revived the will to deal with the past'. Belfast Telegraph 25 June 2010. http://www.belfasttelegraph.co.uk/news/eamesbradleysaville-report-has-revived-the-will-to-deal-with-the-past-28543444.html (accessed 10 January 2016)

Shanahan, S., and M. Sutherland. 2015. 'Crows on the Wire' presentation. 'Beyond the Pale' symposium, Earagail Arts Festival (EAF) 18 July 2015

Verbal Arts Centre. 2013a. 'Crows on the Wire' promotional video.

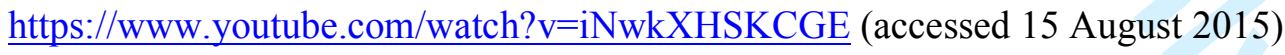

Verbal Arts Centre. 2013b. 'Crows on the Wire' showcased.

http://theverbal.co/blog/story/2013/crows-on-the-wire-showcased (accessed 15 August 2015)

Verbal Arts Centre. 2014a. 'Crows on the Wire' Performance and Discussion Tour. https://www.youtube.com/watch?v=J1oxslz2BGU

Verbal Arts Centre. 2014b. 'Crows on the Wire-The App'.

http://www.crowsonthewire.co/the-app.html (accessed 15 August 2015)

Verbal Arts Centre. 2014c. 'Crows on the Wire' App Vox Pops - November 2014.

https://www.youtube.com/watch?v=MBrpSo-MC4Q (accessed 15 August 2015) 
16

Verbal Arts Centre. 2015. About Us: Why Storytelling? http://theverbal.co/about (accessed 5 January 2016)

Wray, S. 1998. Rhizomes, Nomads, and Resistant Internet Use. The Thing. www.thing.net/ $\sim$ rdom/ecd/rhizomatic.html (accessed 10 July 2015)

URL: https://mc.manuscriptcentral.com/crde 